30. Wells, H. G. Osborne, T. B. The biological reactions to vegetable proteins. I. Anaphylaxis. J. Infec. Dis., 8:66 (1911)

31. We wish to thank the staff of the Animal Unit of the Western General Hospital; Dr. Donald Hanson, for many stimulating discussions, Margaret Gordon for expert technical assistance, and Doreen Orr and Hilary Burns for excellent secretarial help in the preparation of this manuscript. This work was supported by a grant from the Deutsche Forschungsgemeinschaft (DFG Str 210 1 and 210/2-3) and the Medical Research Council.
32. Requests for reprints should be addressed to: Dr. Stephan Strobel, GastroIntestinal Unit Western General Hospital Crewe Road, Edinburgh EH4 $2 \mathrm{XU}$, United Kingdom.

33. This research was supported by grants from the Medical Research Council and the Deutsche Forschungsgemeinschaft

34. Received for publication March 14, 1983

35. Accepted for publication August 12,1983.

\title{
Calcium Metabolism and Cystic Fibrosis: Mitochondrial Abnormalities Suggest a Modification of the Mitochondrial Membrane
}

\author{
AXEL A. VON RUECKER, ROSEMARIE BERTELE, AND H. KARSTEN HARMS
}

Universitaets Kinderklinik, Munich, Federal Republic of Germany

\section{Summary}

A disorder of calcium $\left(\mathrm{Ca}^{2+}\right)$ metabolism may be central to the pathogenesis of cystic fibrosis (CF). Average cellular $\mathrm{Ca}^{2+}$ levels in fibroblasts derived from patients with CF (ages, 14-25 yr; $n$ $=25$ ) were $36-77 \%$ higher than in matched controls depending on age of cell culture $(9.0-10.6$ versus $5.1-7.8 \mathrm{nmol} / \mathrm{mg}$ cellular protein). Cellular $\mathrm{Ca}^{2+}$ was significantly elevated in $\mathrm{CF}$, but was not a reliable criterion for identifying $\mathrm{CF}$ cells because of the high variability of results. Studies of $\mathrm{Ca}^{2+}$ fluxes in cell organelles showed that mitochondria isolated from $\mathrm{CF}$ fibroblasts accumulate 2-3 times more $\mathrm{Ca}^{2+}$ than controls $[79.5 \pm 8.2$ versus 33.7 \pm 4.7 nmols $\cdot \mathrm{mg}$ mitochondrial protein $\left.{ }^{-1} \cdot 10 \mathrm{~min}^{-1}( \pm \mathrm{SD})\right] . \mathrm{Ca}^{2+}$ accumulation in mitochondria reliably distinguished between $\mathrm{CF}$ and control or heterozygote cells $(P<0.0005, n=11)$.

In vitro experiments showed that $\mathrm{Ca}^{2+}$ influx and efflux are increased in isolated $C F$ mitochondria, resulting in net $\mathrm{Ca}^{2+}$ accumulation. $\mathrm{Ca}^{2+}$ uptake in mitochondria is energy-dependent; some inhibitors of mitochondrial energy metabolism (atractyloside, oligomycin) influenced $\mathrm{Ca}^{2+}$ uptake significantly more in $\mathrm{CF}$ than in control mitochondria. Furthermore, the average activities of NADH oxidase, NADH- and succinate-cytochrome reductase were 77,58 , and $48 \%$ higher in CF mitochondria, respectively. This indicates that many functions associated with energy metabolism and the mitochondrial membrane (electron transport, ATP transport, and ATP hydrolysis) are not operating properly in $\mathrm{CF}$, thus possibly causing the derangement of $\mathrm{Ca}^{2+}$ metabolism found in CF mitochondria and cells.

\section{Abbreviation}

\section{CF, cystic fibrosis}

An interesting feature of $\mathrm{CF}$ research is the multiformity of results reported in the literature $(8,33,34)$. Only recently, studies of the Vatican records on dispensations for cousin-cousin marriages have confirmed that $\mathrm{CF}$ is a monogenic autosomal recessive disease with an incidence of up to 1 in 1600 in some Caucasian populations (i.e., northern Europe) (9). Because only a single gene must account for all the phenomenons of $\mathrm{CF}$, it seems reasonable to conceive a working model which would explain this heterogenous exocrinopathy that still is the most common lethal genetic disease in Europe and the United States $(8,35)$

CF must surely involve some basic event of cellular function or the diversity of reported results is hardly comprehensible. The emphasis of our studies was put on $\mathrm{Ca}^{2+}$ metabolism which has been suggested to be central in the pathogenesis of $\mathrm{CF}$ by various authors $(2,3,16,18,28) . \mathrm{Ca}^{2+}$, an intracellular messenger, is linked to many cellular functions $(e, g$, secretion, protein phosphorylation and activation, and protein synthesis: for a recent review see ref. 7). A derangement, therefore, of cellular $\mathrm{Ca}^{2+}$ can cause a variety of different phenomenons, making it a possible candidate for explaining the manifold features reported in CF.

Our study's first aim was to quantify elevated intracellular $\mathrm{Ca}^{2+}$ in $\mathrm{CF}$ and see if it is possible to establish a simple and reliable test to discriminate between $\mathrm{CF}$ and control cells on this basis. Second, $\mathrm{Ca}^{2+}$ metabolism was studied in cell organelles (mitochondria, endoplasmic reticulum) that account for $95-98 \%$ of intracellular $\mathrm{Ca}^{2+}$ and presumably must be affected if intracellular $\mathrm{Ca}^{2+}$ is significantly altered. Our investigations centered on the energy-dependent $\mathrm{Ca}^{2+}$ uptake and $\mathrm{Ca}^{2+}$ efflux in mitochondria which showed to be definitely altered in CF cells. By employing different inhibitors of mitochondrial $\mathrm{Ca}^{2+}$ uptake, ATP transport, ATP hydrolysis and electron transfer, and by measuring electron transfer activities directly, changes in mitochondrial $\mathrm{Ca}^{2+}$ and energy metabolism could be detected in $\mathrm{CF}$. The suggestion of a mitochondrial focus in CF, first made by Feigal and Shapiro, was confirmed $(11,28)$.

\section{MATERIALS AND METHODS}

Cell cultures. Fibroblast cultures were obtained from biopsy specimens of the forearm, after informed consent had been obtained. Thirty-two patients with CF (14-25 yr; mean, $17.3 \mathrm{yr}$ ) were studied. Their clinical status varied from good to severe with Shwachmann scores (31) varying between 34 and 92. Furthermore, 28 obligate $C F$ heterozygotes $(21-33 \mathrm{yr}$; mean, 29.1 yr) and 51 controls (14-30 yr; mean. $18.4 \mathrm{yr}$ ) with no signs of pulmonary disease and in good clinical condition were studied. 
Controls were sex-and age-matched. Flasks (Falcon), $75 \mathrm{~cm}^{2}$, or, for mitochondrial preparations, $110 \times 465-\mathrm{mm}$ roller bottles (Wheaton) were utilized. Fibroblast monolayers were cultured in Eagles minimum essential medium (GIBCO) containing $10 \%$ fetal bovine serum (Boehringer, Mannheim) with $200 \mathrm{U}$ penicillin and $50 \mu \mathrm{g} / \mathrm{ml}$ streptomycin (GIBCO). Cells were grown at $37^{\circ} \mathrm{C}$ in a humidified $95 \%$ air $-5 \% \mathrm{CO}_{2}$ atmosphere and were used at the passages indicated. For storage, cells were frozen in liquid nitrogen at early passages and thawed for use as needed. Removal of cells from stock flasks or roller bottles occurred either by trypsin/EDTA (1:500 trypsin with $0.3 \mathrm{~g} / \mathrm{l}$ EDTA) or by using a rubber scraper as indicated.

Intracellular $\mathrm{Ca}^{2+}$ content. Cells were cultured in the presence of $0.1-0.5 \mathrm{mCi}\left[{ }^{45} \mathrm{Ca}^{2+}\right]$ (New England Nuclear, $30 \mathrm{mCi} / \mathrm{mg}$ ) over different time intervals and then harvested by trypsination. Immediately afterwards, cells were washed once with $0.9 \% \mathrm{NaCl}$ and resuspended in the same former culture medium (including $\left[{ }^{45} \mathrm{Ca}^{2+}\right]$ ) saturated with $95 \%$ air $-5 \% \mathrm{CO}_{2}$ for $2 \mathrm{~h}$. They were shaken occasionally during this period to avoid adherence. Cells were then washed twice with $3 \mathrm{mM} \mathrm{LaCl}, 1 \mathrm{mM}$ EDTA in $0.9 \%$ $\mathrm{NaCl}, \mathrm{pH} 7.4$ at $0^{\circ} \mathrm{C}$ to remove external $\mathrm{Ca}^{2+}$. Contamination of external $\left[{ }^{45} \mathrm{Ca}^{2+}\right]$ was determined by adding $\left[{ }^{45} \mathrm{Ca}^{2+}\right]$ to unlabeled cells during washing. It never exceeded $8 \%$ of intracellular $\mathrm{Ca}^{2+}$. Uptake experiments over three cell doublings, after which at least $87.5 \%$ of total cellular $\mathrm{Ca}^{2+}$ must be in equilibrium with $\left[{ }^{45} \mathrm{Ca}^{2+}\right]$ even if no exchange occurs, indicated that the bulk of cellular $\mathrm{Ca}^{2+}$ had exchanged with $\left[{ }^{45} \mathrm{Ca}^{2+}\right]$ within $24 \mathrm{~h}$, thus verifying the use of $24-\mathrm{h}\left[{ }^{45} \mathrm{Ca}^{2+}\right]$ incorporation as a monitor of total intracellular $\mathrm{Ca}^{2+}$. The specific $\left[{ }^{45} \mathrm{Ca}^{2+}\right]$ activity count $/ \mathrm{min}$ ${ }^{45} \mathrm{Ca} / \mathrm{mol} \mathrm{Ca}$ ) was measured by atomic absorption spectrophotometry and liquid scintillation techniques. Protein determinations were done in aliquots of washed cells by the biuret or Lowry method (21).

Mitochondria preparations. Confluent fibroblast monolayers were treated according to a modified method described by Feigal and Shapiro (11). Roller bottles with attached cells were harvested by prolonged trypsination $(15-20 \mathrm{~min})$ to yield at least 50 $\times 10^{6}$ cells. The cells were then washed twice at $4^{\circ} \mathrm{C}$ with medium A: $200 \mathrm{mM}$ mannitol, $70 \mathrm{mM}$ sucrose, $0.5 \mathrm{mM}$ EGTA, $0.1 \%$ fatty acid free bovine serum albumin, and $10 \mathrm{mM}$ HEPES, adjusted to $\mathrm{pH} 7.2$. The temperature was maintained at $0-4^{\circ} \mathrm{C}$ for all following steps until incubation with $\left.{ }^{45} \mathrm{Ca}^{2+}\right]$. After resuspending the cells in medium $\mathrm{A}(1: 4 \mathrm{v} / \mathrm{v})$, they were homogenized in a tight-fitting Dounce homogenizer with 20-30 strokes. Usually $80-90 \%$ of the cells were disrupted, as determined by microscopy. The homogenate was centrifuged at $1500 \mathrm{~g}$ for $5 \mathrm{~min}$ and the supernate was subsequently centrifuged at $16,000 \mathrm{~g}$ for $15 \mathrm{~min}$ to yield a mitochondrial pellet. The low spin pellet was discarded. Mitochondria were then washed once with medium A without EGTA. The homogeneity of mitochondria was checked by electron microscopy. Protein yield was $2-4 \%$ of original cell protein, containing $23-34 \%$ of succinate dehydrogcnase activity measured in whole cells.

Microsomal preprations. For isolating microsomes, the resultant supernate of the first high-spin mitochondria centrifugation was again centrifuged at $96000 \mathrm{~g}$ for $30 \mathrm{~min}$. The resulting microsomal pellet was washed once in a modified medium $\mathrm{A}$ containing $1 \mathrm{mM}$ mercaptoethanol instead of EGTA and serum albumin. No contaminating mitochondria were detected by electron microscopy. Protein yield was $8-11 \%$ of total cellular protein. No succinate dehydrogenase activity could be detected. Approximately $40 \%$ of total glucose-6-phosphatase activity was associated with this fraction $(n=2)$.

$l^{45} \mathrm{Ca}^{2+} J$ uplake by isolated mitochondria and microsomes Washed mitochondria were resuspended in ice cold medium B containing (final concentrations) $100 \mathrm{mM}$ mannitol, $25 \mathrm{mM}$ sucrose, $50 \mathrm{mM} \mathrm{KCl}, 1 \mathrm{mM} \mathrm{MgCl} 2,2 \mathrm{mM} \mathrm{KH}_{2} \mathrm{PO}_{4}, 0.5 \%$ fatty acid free bovine serum albumin, $10 \mathrm{mM}$ HEPES, adjusted to $\mathrm{pH}$ 7.2. After $2-3 \mathrm{~min}$ a respiratory substrate solution was added to the mitochondrial suspension (final concentrations: $5 \mathrm{mM}$ mal- ate, $5 \mathrm{mM}$ glutamate, $10 \mathrm{mM}$ succinate, $10 \mathrm{mM} \mathrm{ATP}$, pH 7.2). Radioactive $\left[{ }^{45} \mathrm{Ca}^{2+}\right]$ (30 mCi/mg. New England Nuclear) was then added $\left(150 \mu \mathrm{Ci}\right.$; final $\mathrm{Ca}^{2+}$ concentration, $\left.0.2 \mathrm{mM}\right)$ and the mixture was incubated at $37^{\circ} \mathrm{C}$. Samples were drawn at the times indicated in the figures and mixed with ice cold medium $\mathrm{B}$ supplemented with $5 \mathrm{mM}$ EGTA and $8 \mu \mathrm{M}$ ruthenium red (1:5 $\mathrm{v} / \mathrm{v}$ ). This quench medium was used to inhibit $\mathrm{Ca}^{2+}$ fluxes (24). Mitochondria were then separated by centrifugation $(12,000 \mathrm{~g}$; $2 \mathrm{~min}$ ) and the supernate was removed by aspiration. The resulting pellet was washed once with ice cold quench medium in which serum albumin had been omitted. It was then dissolved in $0.1 \%$ Triton X-100. Radioactivity was monitored using the liquid scintillation technique, protein content was determined by the Lowry method (21). To determinate contaminating $\left.{ }^{45} \mathrm{Ca}^{2+}\right]$. mitochondria were incubated as mentioned in the absence of radioactive $\mathrm{Ca}^{2+}$. The quence medium was then added, followed by radioactive $\left[{ }^{45} \mathrm{Ca}^{2+}\right]$. The amount of radioactivity incorporated in these reactions was generally less than $9 \%$ of the maximal $\left[{ }^{45} \mathrm{Ca}^{2+}\right]$ uptake and subsequently subtracted. If inhibitors were used in mitochondria experiments, the controls were done with the same amount of solvent used to dissolve the inhibitor.

Experiments with microsomes were performed similar to those with mitochondria. After incubation and addition of the quench medium the resulting mixture was not centrifuged, but filtered and washed with quench medium on a $0.45-\mu$ millipore filter. Microsomal protein was determined before resuspension in medium $\mathrm{B}$ in a small aliquot as described above. $\left[{ }^{45} \mathrm{Ca}^{2+}\right]$ adhering to the filter was measured by liquid scintillation techniques.

Preparation of submitochondrial particles. For measurement of electron transfer activities, submitochondrial particles were isolated by sonifying isolated mitochondria with a Branson Sonifier, Modell S 75, in potassium phosphate buffer $(100 \mathrm{mM}$, adjusted to $\mathrm{pH} 7.5$ ) at $0-4^{\circ} \mathrm{C}$. The homogenate was then first centrifuged at $8000 \mathrm{~g}$ for $5 \mathrm{~min}$ to remove larger particles and still intact mitochondria. Subsequently centrifugation was performed at $144,000 \mathrm{~g}$ for $60 \mathrm{~min}$ to yield a glassy, greenish-brown pellet (submitochondrial particles). Recovery was approximately $40-60 \%$ of total mitochondrial protein and $60-85 \%$ of succinate dehydrogenase activity.

Enzymatic assals. Spectrophotometric measurements were carried out using a Cary 219 spectrophotometer equipped with waterjacketed cell holders, which were controlled to $\pm 0.5^{\circ} \mathrm{C}$ of the desired temperature. Enzyme activities are expressed as $\mathrm{nmol} \cdot \mathrm{min}^{-1} \cdot \mathrm{mg}$ protein ${ }^{-1}$. NADII dehldrogenase was measured using ferricyanide as electron acceptor according to the method described by Galante and Hatefi (13). The reaction was monitored at $410 \mathrm{~nm}$ and was not inhibited by rotenone. Succinate dehidrogenase was determined by the method of Ackrell 't al. (1), using the artificial electron acceptor phenazine methosulfate and cytochrome $\mathrm{c}$ as terminal oxidant. Antimycin A was added to assure that no electron flux to cytochrome $\mathrm{c}$ and $\mathrm{O}_{2}$ occurs via the respiratory chain. NADH cytochrome c reductase determinations were carried out according to Hatefi and Stignall (15), except for the omission of phospholipid suspensions. Rotenone insensitive contributions were usually less than $14 \%$ and subsequently substracted in all experiments. Succinate cytochrome c reductase measurements were carried out as described by King (19). Crochrome c oxidase is conveniently assayed by the spectrophotometric method of Smith as described by Errede et al. (10). A buffer containing $0.1 \mathrm{M} 2$-(N-morpholino)ethanesulfonic acid was used. For ferrocytochrome c preparations cytochrome $c$ from Sigma was used. The decrease of absorbance of ferrocytochrome c was observed at $550 \mathrm{~nm}$. The reaction was blocked by sodium azide. NADH-oxidase was determined polarographically and spectrophotometrically. Polarographic activities were measured using a Clark-type electrode (Yellow Springs Instrument Co.). A modified method described by King (20) was applied. The assay medium contained $100 \mathrm{mM} \mathrm{KCl}, 20 \mathrm{mM}$ HEPES, $5 \mathrm{mM} \mathrm{KH}_{2} \mathrm{PO}_{4}, 3 \mathrm{mM} \mathrm{MgCl} 2,0.5 \mathrm{mM}$ EDTA, $0.1 \%$ 
fatty acid free bovine serum albumin, $\mathrm{pH}$ 7.2. Cytochrome c ( 3 $\mu \mathrm{M})$ and carbonylcyanide m-chlorophenylhydrazone $(5 \mu \mathrm{M})$ were added shortly before measurements were started. To get appreciable tracings with the oxygen electrode, relatively large amounts of submitochondrial protein were necessary, therefore, a new spectophotometric method was developed as suggested by von Jagow (17). This method measures the decrease of NADH in the presence of submitochondrial particles. The assay medium contained $250 \mathrm{mM}$ sucrose, $50 \mathrm{mM}$ potassium phosphate, $5 \mathrm{mM}$ $\mathrm{MgCl}_{2}, 0.2 \%$ fatty acid free bovine serum albumin, $0.2 \mathrm{mM}$ EDTA, and $2 \mu \mathrm{M}$ carbonylcyanide m-chlorophenylhydrazone, adjusted to pH 7.3. Submitochondrial particles were added and the reaction was started with NADH. Monitoring occurred at $340(-420) \mathrm{nm}$. Addition of antimycin A inhibited the NADH oxidation completely. Sodium azide inhibited the reaction after an initial decrease of NADH, probably due to ferricytochrome c in submitochondrial preparations. Statistical analysis. the Student's $t$ test was used.

Materials. If not stated otherwise all biochemical reagents were obtained from Sigma Chemicals, St. Louis-Munich, Federal Republic of Germany. Salts and solvents were of the purest grade from E. Merck, Darmstadt, Federal Republic of Germany.

\section{RESULTS}

Intracellular $\mathrm{Ca}^{2+}$ in $\mathrm{CF}$, obligate heterozygote, and control fibroblasts. Figure 1 demonstrates that intracellular $\mathrm{Ca}^{2+}$ increased with culture passage (weekly age) in CF and control cells. Average $\mathrm{Ca}^{2+}$ in $\mathrm{CF}$ fibroblasts increased from 9.0 (passage 2) to 10.6 (passage 15$) \mathrm{nmol} / \mathrm{mg}$ cellular protein. $\mathrm{Ca}^{2+}$ in control cells increased from 5.1 (passage 2) to 7.8 (passage 16 ) $\mathrm{nmol} / \mathrm{mg}$ cellular protein. No regression line was plotted for CF heterozygote cells because sufficient data was not present. Sex, age, and clinical status of the fibroblast donors studied were not rated separately because the differences in intracellular $\mathrm{Ca}^{2+}$ were not

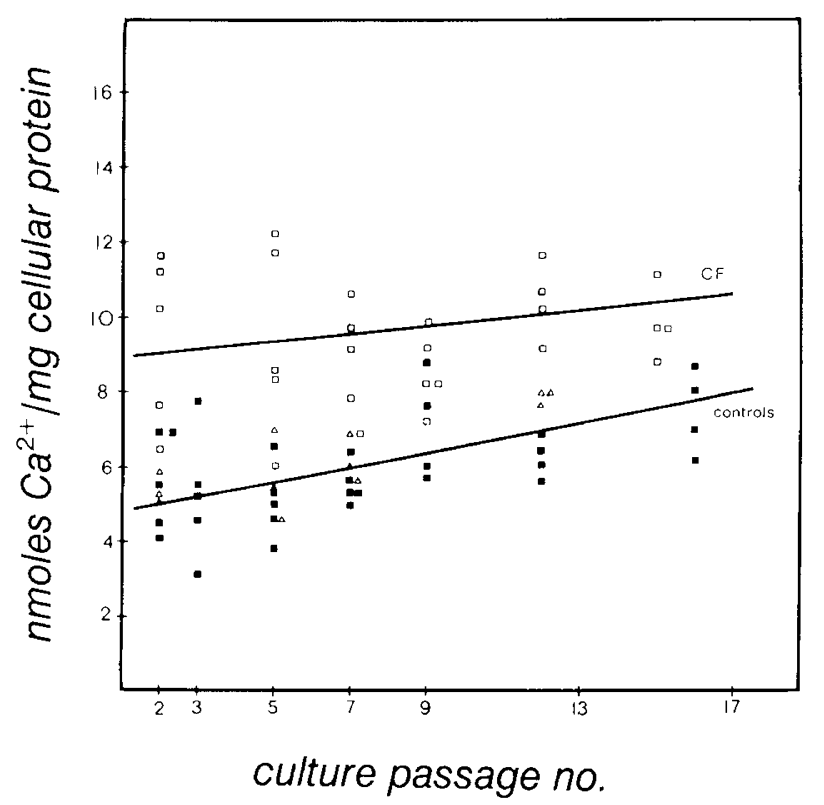

Fig. 1. Intracellular calcium in fibroblasts from patients with cystic fibrosis (CF) $(\square)$, obligate heterozygotes $(\triangle)$, and controls $(\boldsymbol{M})$ as determined by isotope detection. Each symbol represents the mean of duplicate determinations of five different cultures from five different patients (see "Materials and Methods"). Ages of CF patients ranged from 14-25 yr $(n=25)$; obligate heterozygotes, $21-33$ yr $(n=14)$; and controls, 14 $30 \mathrm{yr}(n=23)$. The regression lines represent average intracellular $\mathrm{Ca}^{2+}$, presuming that $\mathrm{Ca}^{2+}$ content increases at a constant rate with cell culture age (culture passage). No regression line was plotted for obligate hetero7.ygote fibroblasts.

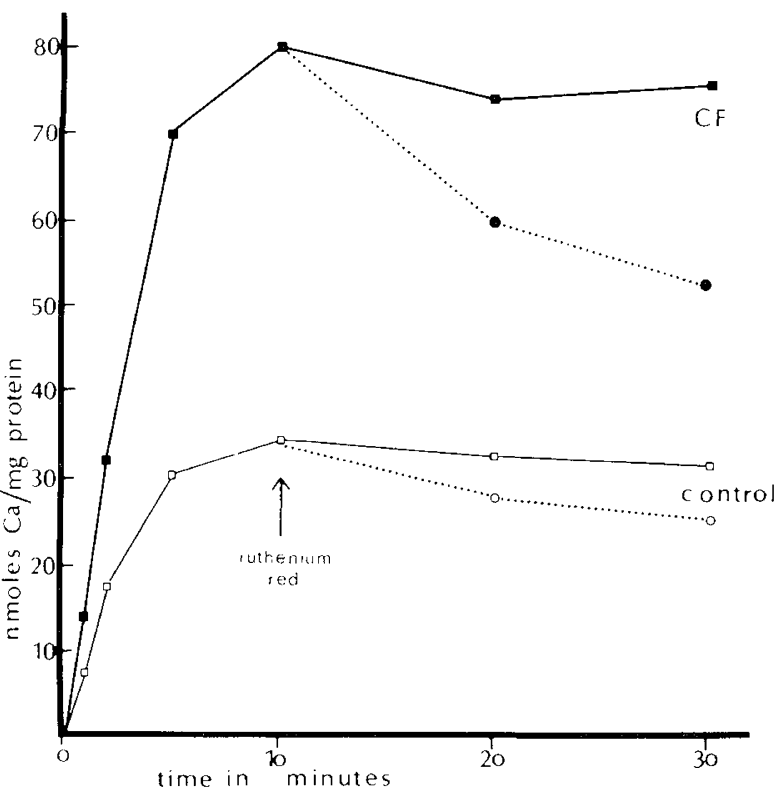

Fig. 2. Kinetic analysis of calcium uptake by mitochondria isolated from cystic fibrosis (CF) fibroblasts $(\square, 0)$ and controls $(\square, O)$. Each symbol represents the mean of duplicate and simultaneous determinations of $\mathrm{Ca}^{2+}$ uptake in mitochondria from one $\mathrm{CF}$ and one control cell strain (cell passage 8). After $10 \mathrm{~min}$ the mitochondrial $\mathrm{Ca}^{2+}$ influx inhibitor ruthenium red (final concentration $2 \times 10^{-5} \mathrm{~mol} / \mathrm{l}$ ) was added to part of the incubation medium and uptake studies continued with $(\boldsymbol{\bullet}$, O) and without $(\mathbf{0}, \square)$ ruthenium red. Mitochondrial protein was less than $0.5 \mathrm{mg} / \mathrm{ml}$. Ca ${ }^{2+}$ uptake was calculated as described (see "Materials and Methods"). The picture shown is representative for $n=11$ studies (see Table 1).

significant. In the case of CF cells, the standard deviation varied between $13-18 \%$ of the mean intracellular $\mathrm{Ca}^{2+}$ value at different passages (controls, $12-16 \%$ ). Statistical analysis showed that $\mathrm{Ca}^{2+}$ was significantly elevated in CF cells at all culture passages, if compared with controls or heterozygote cells $(P<0.03)$. But as Figure 1 shows, intracellular $\mathrm{Ca}^{2+}$ is not a reliable criterion for cell discrimination, because of the high variability of results.

$\mathrm{Ca}^{2+}$ uptake by isolated cell organelles (mitochondria, microsomes). In vitro uptake of $\mathrm{Ca}^{2+}$ in mitochondria and microsomes isolated from $\mathrm{CF}$ and control fibroblasts is demonstrated in Figure 2 and Table 1. Figure 2 shows the time course of $\mathrm{Ca}^{2+}$ uptake by mitochondria. Apparently no further uptake of $\mathrm{Ca}^{2+}$ occured in CF mitochondria and controls after a 10 -min incubation period. The bulk of $\mathrm{Ca}^{2+}$ had entered the mitochondria by 5 min. Under test conditions, maximal $\mathrm{Ca}^{2+}$ uptake was estimated to be in the range of $50-100 \mathrm{nmol} \cdot \mathrm{mg}$ mitochondrial protein ${ }^{-1} \cdot \mathrm{min}^{-1}$ for CF mitochondria (controls, approximately 30-70 $\mathrm{nmol} \mathrm{Ca}{ }^{2+} \cdot \mathrm{mg}^{-1} \cdot \mathrm{min}^{-1}$ ). Table 1 shows that CF mitochondria can accumulate about 2.4 times more $\mathrm{Ca}^{2+}$ than controls and about 2.1 times more than obligate heterozygote mitochondria.

Figure 2 also demonstrates that ruthenium red, an inhibitor of mitochondrial $\mathrm{Ca}^{2+}$ influx, reduced mitochondrial $\mathrm{Ca}^{2+}$ pools if added to the incubation medium after $\mathrm{Ca}^{2+}$ loading had occurred (10 min after start). The maximal $\mathrm{Ca}^{2+}$ efflux in the case of CF mitochondria was estimated to be $2-3 \mathrm{nmol} \cdot \mathrm{mg}$ mitochondrial protein ${ }^{-1} \cdot \mathrm{min}^{-1}$ and was 3-4 times larger than in controls. Because no net uptake of $\mathrm{Ca}^{2+}$ occurred in the absence of ruthenium red after incubating mitochondria for $10 \mathrm{~min}$, it must be assumed that an equilibrium of efflux and influx takes place after the initial $\mathrm{Ca}^{2+}$ uptake phase in both mitochondria from $\mathrm{CF}$ and controls.

Table 1 shows also that unspecific (contaminating) $\mathrm{Ca}^{2+}$ in mitochondria did not exceed $12 \%$ of maximal $\mathrm{Ca}^{2+}$ uptake. This 
was measured by blocking energy-dependent mitochondrial $\mathrm{Ca}^{2+}$ influx by ruthenium red and inhibitors of respiration and ATP hydrolysis. Statistical analysis of the differences in $\mathrm{Ca}^{2+}$ uptake of CF mitochondria and controls or heterozygote mitochondria were highly significant $(P<0.0005)$. Mitochondrial $\mathrm{Ca}^{2+}$ uptake never failed to distinguish homozygous $C F$ cell strains in our tests $(n=11)$

A comparison between microsomes from CF and control fibroblasts (Table 1) showed that there were no significant differences in $\mathrm{Ca}^{2+}$ accumulation either in the presence or absence of mitochondrial $\mathrm{Ca}^{2+}$-uptake inhibitors $(P>0.025)$. Because of the large amounts of cells needed to isolate microsomes and mitochondria (approximately $5-10 \times 10^{7}$ ), culture passage 8 was uniformly studied in these tests. The mitochondrial or microsomal $\mathrm{Ca}^{2+}$ uptake was not rated according to sex, age, or clinical status of cell donor because these differences were not observed as significant within the tested groups.

Inhibition of energy-dependent mitochondrial $\mathrm{Ca}^{2+}$ influx. To localize possible abnormalities of mitochondrial energy metabolism responsible for mitochondrial $\mathrm{Ca}^{2+}$ uptake, different reagents were used to inhibit energy processing at different sites. A quantitative analysis of the influence of these inhibitors on mitochondrial $\mathrm{Ca}^{2+}$ uptake is shown in Table 2. Only 0 time and 10 -min assays were carried out in these tests, contrary to the kinetic analysis mentioned in Table 1 and Figure 2.

Table 1. Calcium uptake by mitochondria and microsomes isolated from fibroblasts of patients with cystic fibrosis (CF), obligate heterozygotes, and controls*

\begin{tabular}{|c|c|c|c|}
\hline & \multicolumn{3}{|c|}{$\begin{array}{c}\mathrm{Ca}^{2+} \text { uptake }\left[\mathrm{nmol} \mathrm{Ca}{ }^{2+} \cdot \mathrm{mg} \text { protein }{ }^{-1} \cdot 10 \mathrm{~min}^{-1}\right. \\
( \pm \mathrm{SD})] \dagger\end{array}$} \\
\hline & $\mathrm{CF}$ & Heterozygotes & Controls \\
\hline Mitochondria & $79.5 \pm 8.2$ & $39.2 \pm 4.3$ & $33.7 \pm 4.7$ \\
\hline Microsomes & $13.4 \pm 1.4$ & $11.1 \pm 1.2$ & $9.8 \pm 0.9$ \\
\hline $\begin{array}{l}\text { Mitochondria } \\
(+ \text { RASO }) \ddagger\end{array}$ & $3.7 \pm 0.9$ & ND & $2.8 \pm 1.2$ \\
\hline $\begin{array}{l}\text { Microsomes } \\
\quad(+\mathrm{RASO}) \ddagger\end{array}$ & $11.2 \pm 0.8$ & ND & $9.1 \pm 0.3$ \\
\hline
\end{tabular}

* Each value represents the mean of duplicate determinations of 11 (mitochondria) or five (microsomes) cell strains. Experiments with RASO were done with two cell strains for each mitochondria and microsomes. Mitochondrial $\mathrm{Ca}^{2+}$ uptake values were derived from kinetic analysis as shown in Figure 2 (see "Methods and Materials"). ND, none detected.

$+\mathrm{Ca}^{2+}$ uptake after the first $10 \mathrm{~min}$ in vitro incubation period was rated.

$\ddagger$ RASO, $20 \mu \mathrm{M}$ ruthenium red, $10 \mu \mathrm{M}$ antimycin $\mathrm{A}, 2 \mathrm{mM}$ sodium azide, and $5 \mu \mathrm{M}$ oligomycin (final concentrations).
Table 2 demonstrates the following points concerning inhibitors. Rotenone (inhibits complex I of the respiratory chain) did not significantly influence $\mathrm{Ca}^{2+}$ uptake in $\mathrm{CF}$ or control mitochondria; however, on an average, it did reduce $\mathrm{Ca}^{2+}$ uptake more in CF mitochondria. Antimycin A (inhibits electron transport in respiratory chain at complex III) decreased $\mathrm{Ca}^{2+}$ uptake by an average of $38 \%$ in $\mathrm{CF}$ mitochondria, and $26 \%$ in controls. Again, these differences were not significant, but CF mitochondria did seem influenced more by antimycin A. Oligomycin (blocks ATP synthase or hydrolysis and has an inhibitory effect on electron transport in respiration) decreased $\mathrm{Ca}^{2+}$ uptake in $\mathrm{CF}$ mitochondria by an average of $61 \%$, but by only $46 \%$ in controls. This difference in inhibitory action was significant $(P<0.05)$. Atractyloside (limits and inhibits adenine nucleotide transport across the mitochondrial membrane) lowered $\mathrm{Ca}^{2+}$ uptake in $\mathrm{CF}$ mitochondria by an average of $39 \%$, but only $12 \%$ in controls. This difference was also significant $(P<0.05)$. The combined action of ruthenium red, antimycin $\mathrm{A}$, and oligomycin decreased mitochondrial $\mathrm{Ca}^{2+}$ uptake by $92-96 \%$ in CF mitochondria and $84-88 \%$ in controls. Contamination rates were comparable to this remaining $\mathrm{Ca}^{2+}$ uptake (see "Materials and Methods").

Electron transfer activities in submitochondrial particles. The experiments with inhibitors of mitochondrial energy metabolism could not eliminate the possibility that electron transport in the respiratory chain may also be affected in $C F$ mitochondria. Figure 3 shows the relative electron transfer activities in $C F$, obligate heterozygote, and control submitochondrial particles. The action of single redox components or complex entities of the respiratory chain like NADH dehydrogenase (complex I), succinate dehydrogenase (complex II), and cytochrome c oxidase (complex IV) was not influenced in all cell strains (Fig. 3 a,b.c). On the other hand, the electron transfer activities markedly changed if two or more redox components of the respiratory chain were involved like in NADH oxidase (complexes I, III and IV), NADH cytochrome $\mathrm{c}$ reductase (complexes I and III), and succinate cytochrome $\mathrm{c}$ reductase (complexes II and III). This can be observed in Figure 3 d,e,f. Comparing CF mitochondrial particles with controls, the average corresponding increases in transfer activities were 77,58 , and $48 \%$, respectively. In the case of obligate heterozygote versus control mitochondria increases were 14,15 , and $22 \%$, respectively. These increases of electron transfer activities in submitochondrial particles of $\mathrm{CF}$ and obligate heterozygote $\mathrm{CF}$ cells were all significant $(P<0.05-0.001)$.

\section{DISCUSSION}

Experiments with fibroblasts grown under optimal conditions have the advantage that the findings are probably not secondarily the consequence of chronic disease or malabsorption as for instance in material derived directly from patients with CF.

Table 2. Effect of different inhibitors on calcium uptake of mitochondria isolated from cystic fibrosis (CF) and control fibroblast: ${ }^{*}$

\begin{tabular}{|c|c|c|c|}
\hline & & \multicolumn{2}{|c|}{$\mathrm{Ca}^{2+}$ uptake } \\
\hline & & $\begin{array}{l}\mathrm{CT} \text { mitochondria } \\
{[\mathrm{nmol} \mathrm{Ca}}\end{array}$ & Controls \\
\hline \multicolumn{2}{|l|}{ No inhibitor } & $83.8 \pm 9.4(100) \dagger$ & $36.7 \pm 5.1(100) \dagger$ \\
\hline \multicolumn{4}{|l|}{ Inhibitor } \\
\hline rotenone & $10^{-5}$ & $70.4 \pm 8.4$ & $34.1 \pm 4.4$ \\
\hline $\operatorname{antimycin} \mathrm{A}$ & $10^{-5}$ & $51.9 \pm 5.9 \quad(62)$ & $27.1 \pm 4.0$ \\
\hline oligomycin & $0.5 \times 10^{-5}$ & $32.7 \pm 4.1$ & $19.8 \pm 2.6$ \\
\hline atractyloside & $10^{-5}$ & $51.1 \pm 4.2$ & $32.3 \pm 3.3$ \\
\hline ruthenium red & $10^{-5}$ & & \\
\hline$+\operatorname{antimycin} \mathrm{A}$ & $10^{-5}$ & $5.0 \pm 1.7$ & $5.1 \pm 0.8$ \\
\hline + oligomycin & $0.5 \times 10^{-5}$ & & \\
\hline
\end{tabular}

${ }^{*}$ Each value represents the mean of duplicate determinations of seven cell strains. $\mathrm{Ca}^{2+}$ associated with mitochondria after 0 min incubation was subtracted from $\mathrm{Ca}^{2+}$ uptake after $10 \mathrm{~min}$ in vitro incubation. No kinetic analysis were performed as shown in Figure 2. $\mathrm{Ca}^{2+}$ uptake was promoted by malate, glutamate, succinate and ATP as described in "Materials and Methods."

$\dagger$ Number in brackets indicates relative $\mathrm{Ca}^{2+}$ uptake, in \%. 


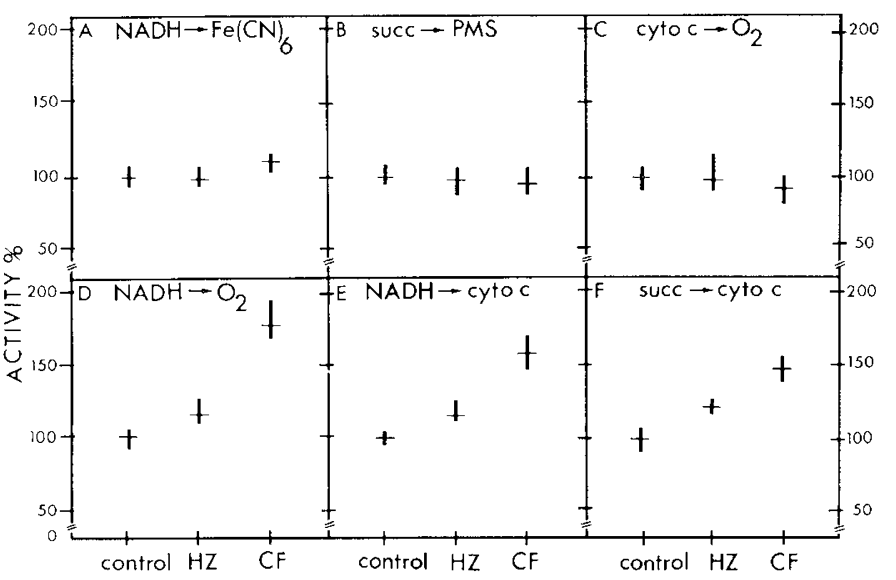

Fig. 3. Relative electron transfer activities in submitochondrial particles from fibroblasts of patients with cystic fibrosis (CF), obligate heterozygotes $(\mathrm{HZ})$, and controls. Each vertical har represents the range of relative electron transfer activities and the horizontal line indicates the mean value. The control mean value was arbitrarily set $100 \%$. Duplicate determinations of electron transfer activities of at least seven different cell strains (cell passage 8) were rated. The ages of cell donors were as described in Figure 1. For enzymatic assays see "Materials and Methods." (.1) NADH-dehydrogenase. (B) succinate-dehydrogenase, (C) cytochrome c oxidase. (D) NADH-oxidase. (E) NADH-cytochrome c reductase, and $(F)$ succinate-cytochrome $\mathrm{c}$ reductase.

Parameters like age. sex. Shwachmann scores, or case history of cell donors were not observed as significant in our tests and cell cultures. The results show that intracellular $\mathrm{Ca}^{2+}$ content is elevated by $36-77 \%$ in $C F$ fibroblasts and depends on the age (passage) of cell culture. Recently similar findings were reported by Shapiro and Lam (29). In a previous study, we were able to confirm that intracellular $\mathrm{Ca}^{2+}$ is also significantly elevated in CF leukocvtes $(2,25,28)$. The discrimination of different cell strains (CF. obligate heterozvgote, control) by intracellular $\mathrm{Ca}^{2+}$ content was not reliable because of the high variability of results. not uncommon in tissuc culture or leukocyte experiments. Nevertheless, high $\mathrm{Ca}^{2+}$ levels in cells mav help identify CF in special cases (e.g. small infants) because intracellular $\mathrm{Ca}^{2+}$ determination by isotope detection is easily and cheaply done with small amounts of cells.

The cell cannot store high amounts of $\mathrm{Ca}^{2+}$ in the cytosol without severe damage or even death $(4,6,12)$. It seemed, therefore. reasonable to expect $\mathrm{Ca}^{2+}$ accumulation in either mitochondria or the endoplasmic reticulum of CF cells. Together these cell organelles store $95-98 \%$ of intracellular $\mathrm{Ca}^{2+}(6,12)$. Our experiments showed that isolated CF mitochondria take up 2-3 times as much $\mathrm{Ca}^{2+}$ as controls or heterozygote $\mathrm{CF}$ mitochondria. Maximal $\mathrm{Ca}^{2+}$ influx and efflux rates were of the same magnitude as those reported for rat liver mitochondria by other authors (12) $\left(\mathrm{V}_{\max }=50-100\right.$ and 2-3 $\mathrm{nmol} \mathrm{Ca}{ }^{2+} \cdot \mathrm{mg}$ mitochondrial protein ${ }^{-1} \cdot \mathrm{min}^{-1}$, respectively). On the other hand, the endoplasmic reticulum (microsomes) of CF cells did not accumulate more $\mathrm{Ca}^{2+}$ in our experiments. Mitochondrial $\mathrm{Ca}^{2+}$ uptake accurately distinguished between CF cell strains and controls or CF heterozygotes (Table 1). For clinical trials, i.e.. prenatal diagnosis of $\mathrm{CF} . \mathrm{Ca}^{2+}$ uptake in mitochondria does not seem practical unless a cheap microassay needing only a small amount of cells can be developed. Elevated uptake of $\mathrm{Ca}^{2+}$ in $\mathrm{CF}$ mitochondria was first observed by Feigal and Shapiro (11).

It has been pointed out in the literature that increased intracellular $\mathrm{Ca}^{2+}$ may be substantial in $\mathrm{CF}(30,32)$. In the cell, the most important action site of $\mathrm{Ca}^{2+}$ is the cytosol, where it performs as a messenger $(5,12,23)$; therefore, it is essential if increased intracellular $\mathrm{Ca}^{2+}$ in CF cells means only higher intramitochondrial or also changed cytosolic $\mathrm{Ca}^{2+}$ levels. Our investigations have shown that $\mathrm{Ca}^{2+}$ uptake and $\mathrm{Ca}^{2+}$ efflux are ele- vated differently in isolated $\mathrm{CF}$ mitochondria. This suggests that the steady-state of cytosolic $\mathrm{Ca}^{2+}$ can be affected in CF cells.

In intact mitochondria $\mathrm{Ca}^{2+}$ efflux is regulated by an antiport $\mathrm{Ca}^{2+}$ translocase that is different from the energy-dependent uniport $\mathrm{Ca}^{2+}$ translocase responsible for $\mathrm{Ca}^{2+}$ uptake (6). If a higher efflux of $\mathrm{Ca}^{2+}$ occurs in CF mitochondria after loading with radioactive $\mathrm{Ca}^{2+}$, this may be due to environmental or intrinsic changes of the antiport $\mathrm{Ca}^{2+}$ translocase or to increased levels of $\mathrm{Ca}^{2+}$ in $\mathrm{CF}$ mitochondria $(6,22)$. On the basis of our experiments neither possibility can be ruled out.

Uptake of $\mathrm{Ca}^{2+}$ by mitochondria is energy-dependent. Our experiments have shown that there are significantly different effects on $\mathrm{Ca}^{2+}$ uptake in CF and control mitochondria by ATP transport inhibitors (atractyloside) and ATP hydrolysis inhibitors (oligomycin) (Table 2). Furthermore, the electron transfer activities of various enzymes or redox components of the respiratory chain (NADH oxidase, NADH cytochrome $c$ reductase and succinate cytochrome $\mathrm{c}$ reductase) were significantly changed in CF mitochondria. These multiple changes of energy processing all involve functions that are associated with the inner mitochondrial membrane. Because CF is presumably a monogenic disease and a single gene must account for these different changes, it seems reasonable that one essential modification of the mitochondrial inner membrane has occurred in CF, changing the action of many membrane-associated enzymes and functions. Nevertheless specific intrinsic changes of the energy-processing enzymes mentioned cannot be ruled out (30).

The finding that electron transport in the respiratory chain is only influenced if two or more redox components are involved (Fig. 3) gives a clue as to what kind of modification may be present in CF mitochondria. Recently, the significance of phospholipids for eliciting the specific catalytic reactions along the electron transfer sequence was demonstrated (14). Increases of electron transfer activities correspond to decreases of phospholipid content in the mitochondrial inner membrane and vice versa. The intrinsic capacity of single redox components such as NADH dehydrogenase and cytochrome c oxidase was not influenced by phospholipid content, but electron transfer was much influenced by phospholipids if two or more redox components were involved $(14,26,27)$. This correlates well with our results and suggests that a defect of membrane phospholipid metabolism may be present in CF mitochondria.

Significant increases of electron transfer activities in coupled redox components were also observed in submitochondrial particles from CF heterozygote cells (Fig. 3 d.e,f). Compared with CF mitochondrial particles. these increases were small but they correlate with the somewhat elevated $\mathrm{Ca}^{2+}$ uptake found in heterozygote mitochondria compared with controls (Table 1). Apparently this mild derangement of mitochondrial energy processing does not greatly effect mitochondrial and cellular $\mathrm{Ca}^{2+}$ uptake (Table 1 and Fig. 1). In summary our results suggest that the disorder of $\mathrm{Ca}^{2+}$ metabolism observed in CF cells probably is generated by a defect of energy and membrane metabolism in CF mitochondria.

\section{REFERENCES AND NOTES}

1. Ackrell, B. A.. Kearney. E. G., and Singer. T. P.: Mammalian succinate dehydrogenase. Methods Enzymol., 53: 466 (1978).

2. Banschbach, M. W. Karam. A. G. Love, P. K., and Hilman, B. C.: Custic fibrosis serum promotes $\left({ }^{45} \mathrm{Ca}\right)$ uptake by normal human leukocytes. Biochem. Biophys. Res. Commun.. 84: 922 (1978).

3. Bogart. B. I.. Picarelli, J., Gaerlan, P. A., and Denning. C. R.: Biological activities of cystic fibrosis serum. IV. Stimulation of the calcium mediated $\mathrm{K}^{+}$efflux from rat submandibular gland fragments. Pediatr. Res., 16: 223 (1982).

4. Borle. A. B.: Control, modulation and regulation of cell calcium. Rev. Physiol. Biochem. Pharmacol. 90: 13 (1981).

5. Carafoli, E. and Crompton. M.: The regulation of intracellular calcium. Curr Top. Membr. Transport. I0: 151 (1978).

6. Carafoli. E: The transport of calcium across the inner membrane of mitochondria. In: E. Carafoli: Membrane Transport of Calcium. pp. 109-140 (Academic Press, London, 1982).

7. Cheung. W. Y.: Calcium and cell function. Vol. I (1980) and Vol. II (1982) (Academic Press. New York). 
8. Davis. P. B. and Sant'Agnese. P. A.: A review. Cystic fibrosis at forty-quo vadis? Pediatr. Res.. 14:83 (1980).

9. Editorial: Cystic fibrosis. Diagnostic hopes. Nature 290: 536 (1981).

10. Errede. B., Kamen. M. D., and Hatefi, Y.: Preparation and properties of complex IV (ferrocytochrome c: oxygen oxidoreductase EC 1.9.3.1). Methods Enzymol. 53: 40 (1978).

11. Feigal, R. J. and Shapiro. B. L.: Mitochondrial calcium uptake and oxygen consumption in cystic fibrosis. Nature. 278: 276 (1979).

12. Fiskum, G. and Lehninger, A. L.: Mitochondrial regulation of intracellular calcium. In: W. Y. Cheung: Calcium and Cell Function. Vol. II. pp. 39-80 (Academic Press. New York. 1982).

13. Galante, Y. M. and Hatefi. Y.: Resolution of complex I and isolation of NADH dehydrogenase and an iron-sulfur protein. Methods Enzymol., 53: 15 (1978).

14. Hackenbrock. C. R.: Review. Lateral diffusion and electron transfer in the mitochondrial inner membrane. Trends Biochem. Sci., 6: 151 (1981).

15. Hatefi, Y. and Stignall, D. L.: Preparation and properties of NADH:cytochrome c oxidoreductase (complex I-III). Methods Enzymol.. 53: 5 (1978).

16. Horton, C. R.. Cole, W. Q., and Bader, H.: Depressed $\left(\mathrm{Ca}^{++}\right)$-transport ATPase in cystic fibrosis erythrocytes. Biochem. Biophys. Res. Commun., 40: 505 (1970)

17. von Jagow, G.: personal communication.

18. Katz. S.: Calcium and sodium transport processes in patients with cystic fibrosis. I. A specific decrease in $\mathrm{Mg}^{2+}$-dependent $\mathrm{Ca}^{2+}$-adenosine triphosphatase activity in erythrocyte membranes from cystic fibrosis patients. Pediatr. Res., 12: 1033 (1978).

19. King. T. E.: Preparations of succinate-cytochrome $\mathrm{c}$ reductase and the cytochrome $b-c_{1}$ particle, and reconstruction of succinate-cytochrome $c$ reductase. Methods Enzymol.. 10:216 (1967).

20. King. T. E.: The Keilin-Hartree heart muscle preparation. Methods Enzymol 10: 202 (1967).

21. Lowry. O. H., Rosebrough, . . J.. Farr. A. L., and Randall, R. J.: Protein measurement with the folin phenol reagent. J. Biol. Chem., 193: 265 (1951).

22. Nicholls, D. G.: The regulation of extramitochondrial free calcium ion concentration by rat liver mitochondria. Biochem. J., 176: 463 (1978).

23. Rasmussen, H. and Goddman, B. P.: Relationship between calcium and cyclic nucleotides in cell activation. Physiol. Rev.. 57: 422 (1977).

24. Reed. K. C. and Bygrave, F. L.: Methodology for in vitro studies of $\mathrm{Ca}^{2+}$ transport. Anal. Biochem. 67: 44 (1976).

25. von Ruecker, A., Baucr. R., Shin, Y. S.. Endres. W.. Bertele. R., and Harms.
K.: Cystic fibrosis--a mitochondrial defect? Eur. J. Pediatr 138:94 (1982) 26. Schneider. H.. Lemasters. J. J.. and Hackenbrock. C. R.: Lateral diffusion of ubiquinone during electron transfer in phospholipid- and ubiquinone-enriched mitochondrial membranes. J. Biol. Chem., 257: 10789 (1982).

27. Schneider, H. and Hackenbrock. C. R. The significance of protein and lipid mobility for catalytic activity in the mitochondrial membranc. In: A. N Martinosi: Membranes and Transport. Vol. 1. pp. 431-435 (Plenum Press, New York. 1982)

28. Shapiro. B. L.. Feigal, R. J., and Lam, L. F-H.: Intracellular calcium and cystic fibrosis. In: J. M. Sturgess: Perspectives in Cystic Fibrosis. Proc. 8th Int. Congr. CF. Toronto, Canada. pp. 15-28 (Imperial Press, 1980).

29. Shapiro, B. L., and Lam, L. F-H.: Calcium and age in fibroblasts from control subjects and patients with cystic fibrosis. Science 216:417 (1982)

30. Shapiro. B. L.. Lam, L. F.H., and Feigal. R. J.: Mitochondrial NADH dehydrogenase in cystic fibrosis: enzyme kinetics in cultured fibroblasts. Am. J. Hum. Gene1. 34: 846 (1982)

31. Shwachmann. H. and Kulczycki, L. L.: Longterm study of one hundred live patients with cystic fibrosis: studies made over a five- to fourteen-year period. Am. J. Dis. Child. 96: 6 (1958).

32. Sorscher. E. J. and Breslow, J. L.: Cystic fibrosis: a disorder of calciumstimulated secretion and transepithelial sodium transport? Lancet, $1: 368$ (1982)

33. Sturgess. J. M.: Perspectives in cystic fibrosis. Proc. 8th Int. Congr. CF. Toronto Canada (Imperial Press. Mississauga. Canada. 1980).

34. Talamo. R. C.. Rosenstein. B. J.. and Berninger. R. W.: Cystic fibrosis. In: J. B. Stanbury; J. B. Wyngaarden: D. S. Fredrickson; J. L. Goldstein, and M. S. Brown: The Metabolic Basis of Inherited Discase. pp. 1889-1917 (McGraw-Hill. New York, 1983).

35. United States. Vital statistics, 1981

36. We are indebted to $G$, von Jagow (Institut für Physiologische Chemie, University of Munich. FRG) and B. L. Shapiro (Department of Oral Biology, University of Minnesota. USA) for valuable help and discussions.

37. Requests for reprints should be addressed to: Dr. Axel von Ruecker. Universitäts Kinderklinik. Lindwurmstr. 4. D-8000 Munich 2. West Germany.

38. This work was supported by a grant from the Deutsche Forschungsgemeinschaft.

39. Received for publication April 18.1983.

40. Accepted for publication September 21, 1983

\title{
Pre- and Postnatal Development of Granulocytic Stem Cells in the Rat
}

\author{
ROBERT D. CHRISTENSEN ${ }^{(22)}$ AND GERALD ROTHSTEIN \\ Departments of Pediatrics and Internal Medicine, University of Utah School of Medicine, and the Primary
}

Children's Medical Center, Salt Lake City, Utah, USA

\section{Summary}

Bacterial sepsis is a relatively common problem in the neonatal period, particularly among prematurely delivered infants. The newborn rat has been widely used as a model for sepsis neonatorum, and in that model incomplete development of the neutrophil system has been postulated to be an important factor predisposing neonates to death from bacterial infection. In this study, that hypothesis was further tested by assessing neutrophil development in rats of various pre- and postnatal ages. Using standard soft agar colony techniques for detecting granulocyte-macrophage progenitor cells $[\mathrm{CFU}(\mathrm{c})]$, the number of $\mathrm{CFU}(\mathrm{c}) / \mathrm{g}$ of body weight was seen to increase from $0.5+0.1 \times 10^{3}$ at $19-20$ days gestation to $10.5 \pm 0.2 \times 10^{3}$ at 4 weeks. The anatomic location of $\mathrm{CFU}(\mathrm{c})$ changed from totally hepatic at 16 days gestation to almost totally myeloid at 4 weeks. Lastly, the proportion of mature, stored neutrophils/CFU(c) decreased from $2440 \pm 40$ at 19-20 days gestation to $430 \pm 75$ at 4 weeks.

\section{Abbreviations}

CFU(c), colony-forming unit in culture PMN, polymorphonuclear leukocyte M5A, McCoy's 5A medium

Very early in gestation, it is unlikely that a fetus, existing in a sterile environment, requires the antimicrobial neutrophil system. Indeed, although red blood cells circulate in the human fetus before the 5 th week of gestation (19), mature neutrophils generally do not appear until after the 12th to 14th week (13) and then exist only in very minute concentration until after birth (16). Because of this late appearance of neutrophils during human gestation, we postulated that infants born prematurely might possess an incompletely developed neutrophil system and that this deficiency might, in part, be responsible for the high incidence of bacterial infection in this group of patients (18). In 